\title{
Clinical Manifestation and Anatomical Location of Endometriosis Based on the Diagnostic Laparoscopic Result
}

\author{
(From Obstetric and Gynecology Policlinic RSUP Dr. Hasan Sadikin Bandung within \\ 2016-2018)
}

\author{
Undang Gani Suriatmaja, Giofani Magdalena, Welly \\ Ratwita \\ Medical Faculty \\ Universitas Jenderal Achmad Yani \\ Cimahi, Indonesia
}

\author{
Trisnu Kamajaya* \\ Medical Faculty \\ Universitas Udayana Kampus Bukit \\ Badung, Indonesia \\ *trisnukamajaya@aol.com
}

\begin{abstract}
Endometriosis is one of common gynecologic disease that mostly founded in reproductive age. The Presence of abnormal endometrial tissues, decreasing quality of life to patients due to pain like dysmenorrhea. The diagnosed can be found based on clinical appearance by laparoscopic method as the gold standard of diagnosing this case. This study was conducted to describe the patient's endometriosis with clinical symptom and results of laparoscopic in RSUP Dr. Hasan Sadikin Bandung from 2016 to 2018 . This descriptive study recruit 100 samples. Data of age collected from secondary data. The data was grouped then processed and presented in tubular form. Most of them here are within reproductive age in 30-34 yars of age at $\mathbf{2 8 \%}$, are mostly nulliparous $\mathbf{7 3 \%}$, with most clinical symptoms of dysmenorrhoea in $74 \%$, and the most common location were to be found within ovarium as much as $85 \%$. According to the study, we can describe that reproductive age and nulliparous were the most dominant characteristic, and most of the clinical symptom are referring to dysmenorrhoea and most anatomical location are within ovarium.
\end{abstract}

Keywords-endometriosis, laparoscopic, diagnostic

\section{INTRODUCTION}

Endometriosis is the growth of endometrial tissue, glands, and stroma outside the uterine cavity or in the myometrium. When endometrial tissue is present in the myometrium, it is called adenomyosis. Endometriosis occurs very frequently in the ovaries, broad ligament, and peritoneal surfaces of the Douglas cavity, including the uterosacral ligament, posterior cervix, etc., rectovaginal septum [1-3]. Endometriosis occurs in 1 to 10 women of reproductive age. The Endometriosis Association Research Registry conducted a study of 3020 cases of endometriosis and found $2-4 \%$ at reproductive age, $40.6 \%$ at $<20$ years, $42.9 \%$ at $20-29$, and $16.5 \%$ at $30-39$ year [4-6]. The problems that are often complained about in endometriosis patients are chronic pelvic pain and infertility [7]. Based on Wiweko et al. 2013 the most seen manifestation were dysmenorrhea (81\%), infertility disorders (33.7\%), low back pain $(32.5 \%)$, dyspareunia $(20.9 \%)$, constipation $(13.9 \%)$, dysuria $(6.9 \%)$, and dyschezia $(4.6 \%)$ [8]. According to the 1997 revision of the American Society for Reproductive Medicine, the staging classification of endometriosis is based on the type, location, appearance, depth of lesion invasion, disease spread, and adhesions. The gold standard examination performed to diagnose endometriosis is diagnostic laparoscopy [9]. Based on the description above, researchers are interested in conducting research that is will be done in Dr. Hasan Sadikin Bandung, which is the highest referral hospital in West Java. This research will look for a picture of clinical symptoms and the anatomical location of endometriosis based on the results of the diagnostic laparoscopy at Obstetrics and gynecology polyclinic Dr. Hasan Sadikin Bandung for the period 2016-2018.

\section{A. Ethiopathogenesis}

The retrograde menstruation theory was developed by Sampson in 1927. This was confirmed by a laparoscopic examination which proved that there was a reverse flow of menstrual blood that flowed back through the tube into the pelvic cavity (retrograde). Based on this theory, endometriosis is a consequence of the backflow of menstrual blood through the fallopian tubes, which continues with implantation and growth in the peritoneum and ovaries [7].

Lymphatic and vascular embolism theory explains the mechanism of endometriosis in the outer regions pelvis. The retroperitoneal area has a lot of lymphatic circulation. A study showed that $29 \%$ of women suffering from endometriosis was found lymph nodules in the pelvis. In addition, the spread of adenocarcinoma via the lymphatic route supports the theory that endometriosis can spread via the lymphatic route [7].

Coelomic Metaplasia Theory was put forward by Robert Meyer, who stated that endometriosis occurs due to certain 
stimulation, were to be dominantly coming from hormone within parietal peritoneum cell which is a pluripotent tissue [7].

Immunologic and genetic theory were to seen as immune disorders occur in women who suffer from endometriosis. A study found a failure in the system for collecting and removing waste substances during menstruation by macrophages and decreased Natural Killer (NK) cell function in endometriosis. Several studies have found an increase in Immunoglobulin A ( $\operatorname{IgA}), \operatorname{IgG}$ and $\operatorname{IgM}$ in the peritoneal serum of patients with endometriosis [7].

\section{B. Anatomical Location and Manifestation of Endometriosis}

Most commonly, endometriosis is found in the pelvic area. The ovaries, pelvic peritoneum, anterior and posterior culdesac, and uterosacral ligaments are also frequently involved. In addition, it can be found in the rectovaginal septum, ureters and bladder. The clinical symptoms of endometriosis will peak in the premenstrual state, then subside after menstruation is over [7]. Pelvic pain is the most common symptom. Other symptoms are dysmenorrhea, pain in the bladder or dysuria, dyspareunia, dyschezia, and some patients even present with complaints of infertility $[10,11]$.

\section{Risk Factors}

Genetics as a risk factor was studied in the Oxford Endometriosis Gene (OXEGENE) study, an international collaborative project that has attempted to identify the locus of vulnerability using linkage analysis. Which is significant on chromosome 10q26. Chromosome 10q26 has previously been involved in gene studies, and the results reported aberrant endometrial EMX2 expression in women with endometriosis. EMX2 itself plays a role in coding the transcription factors needed in the development of the reproductive tract. But to date, there are no official studies that confirm whether EMX2 contributes or not to the development of endometriosis $[12,13]$.

Meanwhile, women whose mothers or sisters have endometriosis have a seven times greater risk of experiencing endometriosis. The incidence of endometriosis is $10-20 \%$ in women of reproductive age, rarely occurs at the age of premenars or menopause [14]. Women with short menstrual cycles can increase the risk of exposure to menstruation which will have an increased risk of retrograde menstruation/reflux, making it easier for endometriosis. This shortening of the menstrual cycle increases the hormone estrogen exposure compared to women who have long menstrual cycles [15].

The development and growth of endometriosis tissue depend on sex steroid hormones and local growth factors such as insulin-like growth factor 1 (IGF-1) or vascular endothelial growth factor (VEGF). Estrogen increases sharply in the short time before ovulation; estrogen itself has a synergistic effect with IGF-1 / VEGF and sometimes actually enhances the effect of IGF-1 / VEGF on the proliferation and mitosis of ectopic endometrial cells, which will result in the formation of endometriosis [16]. During the menstrual cycle of patients with endometriosis, cyclic bleeding can occur in the nasal cavity, which occurs due to the presence of estrogen receptors on the mucosal surface of the respiratory tract; this can occur due to an imbalance in the secretion of matrix metalloproteases (MMPs) and tissue inhibitor of metalloproteases (TIMPs) [17].

\section{Diagnosing Endometriosis}

The physical examination of endometriosis begins with an inspection of the using a speculum, followed by bimanual examination and palpation of the rectovagina. Examination during menstruation can increase the chances of detecting endometriosis nodules and also assess pain $[7,18]$.

Ultrasound is used as the first-line examination performed on patients where the pelvic disease is suspected. Ultrasound has good resolution, easy accessibility, is inexpensive, and free from radiation. Although ultrasound has limitations for diagnosing peritoneal endometriosis, it is very effective in diagnosing endometrioma.

MRI is a good alternative non-invasive diagnostic method where the entire pelvic state can be visualized with high specificity and sensitivity, especially for detecting deep infiltrating endometriosis / deep nodular endometriosis and endometrioma. The disadvantage of MRI is its inability to detect small $(<3 \mathrm{~mm})$ peritoneal lesions [10]

Laparoscopy is the main method or gold standard used to diagnose endometriosis. Laparoscopic findings that were seen were discrete endometriosis lesions, endometrioma, and adhesions formation. The examination is carried out during the menstrual cycle in the proliferative phase until the early secretory phase so that endometriosis can be visualized properly. Operative laparoscopy requires three basic components, namely skills, equipment, instruments, operating room facilities, and an operating team trained. Its advantages are minimal bleeding, a high degree of operative precision, low complications, short treatment time, and minimal surgical wounds $[7,8,19]$.

\section{RESEARCH METHODS}

This research method is descriptive research. This study used secondary data, namely the medical records of endometriosis patients with clinical symptoms and the results of laparoscopy at the Obstetrics and Gynecology Polyclinic of Dr. Hasan Sadikin Bandung for the period 2016-2018. From 417 medical records of patients with a diagnosis of Endometriosis, the study sample was selected. It was obtained 220 medical records of patients diagnosed with Endometriosis, which performed diagnostic laparoscopy in accordance with the inclusion and exclusion criteria, then the number of samples in this study was 100 samples using the simple random sampling method. The variables in this study were age, parity, clinical features, and anatomical location. 


\section{RESULTS AND DISCUSSION}

\section{A. Description of Age Characteristics of Endometriosis Patients in Obstetrics and Gynecology Polyclinic Dr. Hasan Sadikin Bandung within 2016-2018}

TABLE I. DESCRIPTION OF THE CHARACTERISTICS OF ENDOMETRIOSIS PATIENTS BY AGE

\begin{tabular}{|l|l|l|}
\hline \multicolumn{1}{|c|}{ Age (year) } & \multicolumn{1}{c|}{ n } & \multicolumn{1}{c|}{$\%$} \\
\hline $20-24$ & 23 & 23 \\
\hline $25-29$ & 20 & 20 \\
\hline $30-34$ & 28 & 28 \\
\hline $35-39$ & 17 & 17 \\
\hline $40-44$ & 12 & 12 \\
\hline $45-49$ & 0 & 0 \\
\hline Total & 100 & 100 \\
\hline
\end{tabular}

Based on Table 1 the description of age within 100 endometriosis patient group found that the age of endometriosis patients at the Obstetrics and Gynecology Polyclinic Dr. Hasan Sadikin Bandung for the period 20162018 were mostly in the age range $30-34$ years with a total of 28 people (28\%) [20]. This study's results are almost the same as research conducted by Hestiantoro et al. shows that the largest age group is $30-34$ years $(29.72 \%)$. The results of this study indicate that endometriosis in women of reproductive age will have a greater effect on the quality of life of these patients. Therefore, early case findings will reduce serious complications so as not to affect the patient's quality of life [21].

\section{B. Description of Parity Characteristics of Endometriosis Patients in Obstetrics and Gynecology Polyclinic Dr. Hasan Sadikin Bandung Period 2016-2018}

TABLE II. CHARACTERISTICS OF PARITY WITHIN ENDOMETRIOSIS

\begin{tabular}{|l|l|l|}
\hline \multicolumn{1}{|c|}{ Parity } & \multicolumn{1}{c|}{ n } & \multicolumn{1}{c|}{$\%$} \\
\hline Nullipara (P0) & 73 & 73 \\
\hline Primipara (P1) & 19 & 19 \\
\hline Multipara (P2) & 3 & 8 \\
\hline Total & 100 & 100 \\
\hline
\end{tabular}

From what we could see from Table 2, shows that the most endometriosis patients were to be dominantly nulliparous, with a total of 73 people $(73 \%)$. The results of this study are in accordance with research conducted by Abadi, which was found to be almost the same, showing that $46 \%$ of patients were nulliparous. Research conducted by Rajuddin and Jacoeb is also in line with the results of this study which found 26 cases $(81.3 \%)$ were to be nulliparous. Based on several clinical and epidemiological research data results, there is an indication of a relationship between a history of parity and a risk factor for endometriosis [21].

\section{Overview of Clinical Symptoms of Endometriosis Patients in Obstetrics and Gynecology Polyclinic Dr. Hasan Sadikin Bandung Period 2016-2018}

TABLE III. DESCRIPTION OF CLINICAL SYMPTOMS OF PREDOMINANT COMPLAINTS WITHIN ENDOMETRIOSIS PATIENTS

\begin{tabular}{|l|l|l|}
\hline \multicolumn{1}{|c|}{ Chief Complaint } & \multicolumn{1}{|c|}{ n } & \% \\
\hline Dysmenorrhea & 74 & 74 \\
\hline Infertility & 20 & 20 \\
\hline Pelvic Pain & 5 & 5 \\
\hline Dyspareunia & 1 & 1 \\
\hline Disuria & 0 & 0 \\
\hline Dyskezia & 0 & 0 \\
\hline Total & 100 & 100 \\
\hline
\end{tabular}

Table 3, show that the most common complaint is dysmenorrhea, with a total of 74 people $(74 \%)$. The results of this study are in accordance with research conducted by Abadi, which showed that dysmenorrhea was the most frequently complained of symptoms, namely 23 cases (70\%). Another study conducted by Pangemanan et al. showed that dysmenorrhea was found in 31 cases $(93.9 \%)$ [18]

The clinical symptoms felt by the patients were mostly dysmenorrhea; this is related to the role of proinflammatory cytokines that act on endometriosis lesions resulting in the production of large amounts of prostaglandin E2 (PGE2), and it may increase neuronal invasion by stimulating the formation of NGF and other neurotrophins. This results in persistent inflammatory pain and inhibits neuronal apoptosis. There was an increase in nerve fiber density in peritoneal lesions of women with endometriosis compared to women without endometriosis [22]. The data from the dysmenorrhea group were more frequent in lesions in the uterus, whereas from this study, it was found that the location of the lesions was mostly in the ovaries.

Infertility was also found in this study, as much as $20 \%$. Because the abnormal cell growth of endometriosis will grow along with the increase in body estrogen and progesterone levels. Endometrial tissue grows outside the uterus from the fallopian tubes infundibulum to the ovary were the most dominant location where it develops. Therefore, the ovary is the first part of the pelvic cavity to be affected by endometriosis [23]. Adhesions can also occur around the uterus and fallopian tubes. Adhesions in the uterus cause the uterus to grow retrovert, while adhesions in the fallopian tubes cause the spontaneous movement of the fimbriae's ends to carry the ovum to the uterus to be obstructed. These things cause infertility in endometriosis. Chronic pelvic pain in endometriosis can also be caused by irritation and infiltration of the pelvic floor nerves. Chronic pelvic pain occurs when the endometriosis lesion is on the lateral wall of the pelvis.

Dysuria is a symptom of endometriosis that is rarely complained of by endometriosis patients. This is based on the theory that dysuria is caused by infection. So that the diagnosis of endometriosis may be suspected if the urine culture results are negative. Dychezia is also a minor common symptom in 
patients with endometriosis. Dyschezia usually reflects the presence of a rectosigmoid endometriosis implant.

\section{Overview of the Anatomical Location of Endometriosis Patients in the Obstetrics and Gynecology Polyclinic Dr. Hasan Sadikin Bandung Period 2016-2018}

TABLE IV. OVERVIEW OF LAPAROSCOPIC RESULTS FOR ENDOMETRIOSIS PATIENTS BASED ON THE LOCATION OF THE ENDOMETRIOSIS

\begin{tabular}{|l|l|l|}
\hline \multicolumn{1}{|c|}{ Endometriosis location } & \multicolumn{1}{|c|}{ n } & \multicolumn{1}{c|}{$\%$} \\
\hline Ovarium & 85 & 85 \\
\hline Uterus & 7 & 7 \\
\hline Fallopian Tube & 8 & 8 \\
\hline External Organ & 0 & 0 \\
\hline Total & 100 & 100 \\
\hline
\end{tabular}

Table 4 shows that the anatomical location of the most endometriosis patients is the ovary, with a total of 85 people $(85 \%)$. The results of this study are in accordance with that conducted by Abadi. It was found that the largest distribution was the ovaries, as many as 27 cases $(82 \%)$. Then another study conducted by Pangemanan et al. (2007) also obtained the same results, namely from 33 endometriosis patients, 26 patients $(78.8 \%)$ of whom were located in the ovary [18]

Endometriosis can occur because menstrual blood flows back through the tubes into the pelvic cavity (retrograde). So that the ovary can become the pelvic organ most often affected by the endometriosis process [3]. Endometrial cells in the ovary can enter the bloodstream and spleen because they are influenced by hormonal cycles, so when changes in estrogen and progesterone levels are lower or reduced, this endometrial tissue there will be necrosis and bleeding in the pelvic area. Bleeding in the pelvic area is caused by irritation of the peritoneum and causes dysmenorrhoea [10,13]. Endometriosis that occurs in the ovaries can form brown cysts or often refer to as brown cysts, which can cause adhesions with other organs and form a complete unity. The features of ovarian endometriosis vary, from small lesions to large cysts [10].

\section{CONCLUSION}

Based on research at the Obstetrics and Gynecology Polyclinic Dr. Hasan Sadikin Bandung for the 2016-2018 period can draw conclusions (1) The characteristics of endometriosis patients based on age were mostly in the age range 30-34 years as many as 28 people (28\%), and based on the most parity nulliparous were to be dominantly found as many as 73 people (73\%) (2) The most common complaint was dysmenorrhea within 74 people (74\%). (3) The anatomical location of endometriosis is mostly found in the ovaries, with a total of 85 people $(85 \%)$.

For further research, it is also advisable to look at the types of endometriosis lesions, as well as the relationship between endometriosis and the incidence of infertility in these patients. For further research, advisable to do research with wider variables and with different data processing as it will increase the knowledge of other students about endometriosis.

\section{REFERENCES}

[1] B.L. Hoffman, J.O. Schorage, K.D. Bradshaw, L.M. Halvorson, J.I Schaffer, and M.M. Corton, Williams Gynecology, 3rd ed. New York: McGraw Hill, 2016, pp. 285-7.

2] N.F. Hacker, J.C. Gambone, and C.J. Hobel, Hacker \& Moore's essentials of obstetrics and gynecology. Germany: Elsevier Health Sciences, 2015

[3] J.S. Berek, Berek \& Novak's Gynecology, 14th Edition. Philadelphia: Lippincott Williams \& Wilkins, 2007, pp. 1138-56.

[4] P.A. Rogers, T.M. D’Hooghe, A. Fazleabas, C.E. Gargett, L.C. Giudice G.W. Montgomery, ... and K.T. Zondervan, "Priorities for endometriosis research: recommendations from an international consensus workshop,' Reprod sci., vol. 16, no. (4), pp. 335-46, 2009

[5] S. Abbas, P. Ihle, I. Köster, and I. Schubert, "Prevalence and incidence of diagnosed endometriosis and risk of endometriosis in patients with endometriosis-related symptoms: findings from a statutory health insurance-based cohort in Germany," European Journal of Obstetrics \& Gynecology and Reproductive Biology, vol. 160, no. (1), pp. 79-83, 2012

[6] W. Hanifa, Gynecology, Third Edition. Jakarta: PT. Bina Pustaka Sarwono Prawiharjo, 2011, pp. 239-40.

[7] J.O. Schorge, J.I. Schaffer, L.M. Halvorson, B.L. Hoffman, K.D Bradshaw, and F.G. Cunningham, Williams gynecology, 2nd ed. China: The McGraw-Hill, 2012, pp. 281-98.

[8] B. Wiweko, C.G. Puspita, K. Sumapraja, M. Natadisastra, A.K. Harzief, H. Situmorang, ... and A. Hestiantoro, "Penggunaan DLBS1442 untuk Terapi Medikamentosa Terkini pada Penderita Endometriosis," Med 2017, vol. 26, no. (2), pp. 4-7, 02 August 2017.

[9] L. Speroff and M.A. Fritz, "Endometriosis," In: Clinical Gynecologic Endocrinology and Infertility, 8th ed. Philadelphia: Lippincott William \& Wilkins, 2018, p. 955.

[10] S.J. Bagaria, D.D. Rasalkar, and B.K. Paunipagar, Endometriosis - basic concepts aand current research trends. China: InTech, 2012, pp. 437-46.

[11] B.A. Magowan, P. Owen, and J. Drife, Clinical obstetrics \& gynaecology, 2nd ed. China: Saunders Elsevier, 2009, pp. 1-140.

[12] S. Kennedy, "The genetics of endometriosis," European Journal of Obstetrics \& Gynecology and Reproductive Biology, vol. 82, no. (2), pp. 129-133, 1999.

[13] S. Prawihardjo, "Endometriosis," Dalam M. Anwar, A. Baziad, dan R.P. Prabowo, Ilmu Kandungan, Edisi 3. Jakarta: PT Bina Pustaka Sarwono Prawihardjo, 2011, pp. 239-49.

[14] K.C. Abadi, Gambaran endometriosis di laboratorium patologi anatom RSUP DR. M. Djamil Padang periode 2010-2013. Padang: Fakultas kedokteran Universitas Andalas, 2014

[15] M. Wei, Y. Cheng, H. Bu, Y. Zhao, and W. Zhao, "Length of menstrual cycle and risk of endometriosis: a meta-analysis of 11 case-contro studies," Medicine, vol. 95, no. (9), p. 2922, 2016.

[16] N. Machairiotis, A. Stylianaki, G. Dryllis, P. Zarogoulidis, P Kouroutou, N. Tsiamis, ... and C. Machairiotis, "Extrapelvic endometriosis: a rare entity or an under diagnosed condition?' Diagnostic Pathology, vol. 8, no. (1), pp. 1-12, 2013.

[17] E. Weisberg and I.S. Fraser, "Contraception and endometriosis: challenges, efficacy, and therapeutic importance," Open access journal of contraception, vol. 6, pp. 105-15, 2015 .

[18] A.L. Mounsey, A.S. Wilgus, and C. David, "Diagnosis and management of endometriosis," J Am Fam Physician, vol. 74, no. (1), pp. 594-602, 2006 
[19] W. Hadisaputra, "Perkembangan Laparoskopi Operatif di Indonesia," eJKI, vol. 2, no. (2), pp. 65-9, 2014.

[20] A. Hestiantoro, A. Baziad, dan A. Puspasari, Karakteristik Pasien Endometriosis di Rumah Sakit Dr. Cipto Mangunkusumo Periode 20002005. Jakarta: Fakultas Kedokteran Universitas Indonesia, 2007.

[21] Rajuddin dan T.Z. Jacoeb, "Penanganan Adenomiosis dengan Reseksi Laparotomi," Dalam Majalah Obstetri Ginekologi Indonesia, vol. 32, no. (1) (Edisi Januari), pp. 23-25, 2008.
[22] P. Vercellini, L. Fedele, G. Aimi, G. Pietropaolo, D. Consonni, and P.G. Crosignani, "Association between endometriosis stage, lesion type, patient characteristics and severity of pelvic pain symptoms: multivariate analysis of over 1000 patients," Human reproduction, vol. 22, no. (1), pp. 266-271, 2007.

[23] A. Wahyuni, "Endometriosis dan infertilitas," Mutiara Medika, vol. 8, no. (1), pp. 62-71, 2008 